\title{
Bigger and sweeter passion fruits: effect of pollinator enhancement on fruit production and quality
}

\author{
Camila N. JunqueirA ${ }^{1,2}$, Solange C. Augusto ${ }^{1}$ \\ ${ }^{1}$ Universidade Federal de Uberlândia, Instituto de Biologia, Campus Umuarama, CEP: 38400-902, Uberlândia, MG, \\ Brazil \\ ${ }^{2}$ Universidade Federal de Uberlândia, Escola Técnica de Saúde, Campus Umuarama, CEP: 38400-902, Uberlândia, MG, \\ Brazil
}

Received 12 February 2016 - Revised 20 May 2016 - Accepted 15 June 2016

\begin{abstract}
Brazil stands out as the world's largest producer of yellow passion fruit, a species of economic interest which, due to its self-incompatibility, depends on pollinators for fruit formation. The main pollinators of passion fruit are large solitary bees of the genus Xylocopa, commonly known as carpenter bees, which are potential candidates for management. Passion fruit crops exhibit a low density of pollinators and, consequently, a reduction in production. To improve management techniques of $X$. frontalis and X. grisescens, the general aim of this study was to evaluate the effect of pollinator enhancement on pollination services in passion fruit crop areas. Our results demonstrated that pollinator enhancement was an efficient way to minimize pollination deficit in passion fruit crops, as it promoted the production of a bigger and sweeter fruits. Data obtained in our study are essential to consolidate management techniques for carpenter bees in passion fruit crops.
\end{abstract}

crop pollination / fruit quality / passion fruit / carpenter bees / nest management

\section{INTRODUCTION}

Human food production relies on a variety of inputs including soil quality, water availability, and pest management (Pretty 2008). Among these, pollination by bees stands out as a major natural input accounting for the production of $75 \%$ of the world's agricultural crops, including important species that are sources of micronutrients (Klein et al. 2007; Ellis et al. 2015).

The economic valuation of ecosystem services provided by pollinators exceeds $€ 150$ billion annually (Gallai et al. 2009). Furthermore, other factors associated with agricultural production, such as fruit quality and oil quantity in seeds, which add greater value to the product, thereby

Corresponding author: C. Junqueira, camilajunqueira@ufu.br

Manuscript editor: Klaus Hartfelder increasing its market price, are also associated with pollinators' richness and abundance (Hanley et al. 2015). Even for self-compatible crops, such as sunflower (Helianthus annuus) and coffee (Coffea arabica), natural pollination is related to an increase in production yields (Ricketts 2004; Greenleaf and Kremen 2006).

The pollinator decline has cooperated to the reduction of both $A$. mellifera and native wild pollinator populations, which contributes to a yield gap in agricultural production, i.e., a difference between the actual and the potential output (Bommarco et al. 2013). This decrease originates from exogenous recurrent factors, such as land use intensification, indiscriminate use of pesticides, climate changes, and incidence of viruses and parasites (Wilcock and Neiland 2002; Potts et al. 2010; Dupont et al. 2011). In this scenario, the increment of ecosystem services, such as the increment of natural pollination through the management of 
pollinators, is a sustainable alternative to minimize this decline and contribute to the maintenance and increase of agricultural production (Bommarco et al. 2013; Steward et al. 2014).

Ecological intensification through the management of pollinators in crop areas has been widely used, especially with A. mellifera, which stands out as the most worldwide managed pollinator due to its easy mobility, highly populated colonies, and for presenting generalist food preferences (Westerkamp 1991; Klein et al. 2007). However, the dependence on a single pollinator for pollination of agricultural crops endangers food production stability, due to the higher vulnerability of crops faced with pollinator decline. Furthermore, A. mellifera may not be an efficient pollinator of some crops, due to its foraging behavior or flower morphology incompatibility (Bispo dos Santos et al. 2009; Junqueira et al. 2013).

Wild bees play a crucial role in crop pollination due to their greater pollination efficiency compared to honey bees in some crops. They are also a viable alternative to the dependence on a single pollinator (Garibaldi et al. 2013). Experiments with apple crops evidenced that Bombus spp. exhibits a greater pollen deposition onto the stigma than A. mellifera (Thomson and Goodell 2001). In blueberry crops, Bombus spp. and Andrena spp. presented a greater visitation rate and fruit production than A. mellifera (Javorek et al. 2002). Thus, the development of management procedures that enhance wild pollinators is essential to increase agricultural production, reducing food insecurity and contributing to the conservation of these pollinators.

The management of solitary species is widely developed for cavity-nesting bees (Bosch and Kemp 2001, 2002; Magalhães and Freitas 2012) and some ground-nesting bees like the Bluebanded bee, Amegilla (Zonamegilla) holmesi, managed for tomato (Lycopersicon esculentum Miller) pollination through the introduction of nesting bricks filled with mud (Hogendoorn et al. 2000; Bell et al. 2006).

Brazil is the world's largest producer of yellow passion fruit (Passiflora edulis f. flavicarpa
Deneger). This fruit species is of high economic interest with a production above $800,000 \mathrm{t}$ per year (Agrianual Anuário Estatístico da Agricultura Brasileira 2014). Due to its self-incompatibility, this crop depends on pollinators for fruit formation (Corbet and Willmer 1980).

The main pollinators of passion fruit are large solitary bees of the genus Xylocopa, which nesting habits includes preexisting cavities and, therefore, are potential candidates for management (Pereira and Garófalo 2010; Junqueira et al. 2012). Other floral visitors include $A$. mellifera and stingless bees, which are small to middle sized bees (Michener 2007) and are considered pollen thieves, as they do not contact the flower reproductive structures during pollen and/or nectar collection (Sazima and Sazima 1989).

Xylocopa (Neoxylocopa) frontalis (Olivier) and Xylocopa (Neoxylocopa) grisescens Lepeletier are effective pollinators of passion fruit and are easily managed in trap-nests made of bamboo canes (Junqueira et al. 2012, 2013). The use of such substrate combined with the introduction of nests in crop areas of passion fruit proved to be an effective strategy to establish populations, increase pollinators' density, and reduce the density of thieves (Junqueira et al. 2013).

Passion fruit crops exhibit a low density of pollinators because of the reduction of natural vegetation surrounding these crops, which implies a reduction of food and nesting resources (Camillo 2003; Yamamoto et al. 2012). The pollinator deficit in these crops has been minimized with the use of manual pollination. However, this practice is expensive and raises production costs up to $12 \%$ (Agrianual Anuário Estatístico da Agricultura Brasileira 2014).

To improve management techniques of $X$. frontalis and $X$. grisescens, the overall aim of this study was to evaluate the effect of pollinator enhancement on pollination services in passion fruit crop areas. To address this issue, we set up the amount of pollinator nests per hectare according to the pollination deficit and assessed the effect of pollinator enhancement on passion fruit production and quality. 


\section{MATERIAL AND METHODS}

\subsection{Study areas}

The study took place throughout the passion fruit flowering season (November 2014 to June 2015) and was accomplished in six crop areas with sizes ranging from 1 to 3 ha, located in Araguari and Uberlândia, Triângulo Mineiro region, state of Minas Gerais, southeastern Brazil (Table I). All crop areas used the same variety of yellow passion fruit and similar technical agronomic assistance. The climate is tropical and characterized by two distinct seasons, a dry season (April-September) and a rainy season (OctoberMarch) (Rosa et al. 1991).

\subsection{Procedures}

\subsubsection{Pollinator enhancement experiment}

In each crop area, we constructed a bee shelter with a yellow plastic cover of $1.8 \mathrm{~m}$ high and $1 \mathrm{~m}$ long. Each bee shelter contained 48 trap-nests made of bamboo canes, closed at one end by the node and with an inner diameter ranging from 1.8 and $2.2 \mathrm{~cm}$ and length of approximately $25 \mathrm{~cm}$. The pollinator enhancement experiment included both the supply of nest substrate and the introduction of $X$. frontalis and $X$. grisescens nests.

The areas were classified according to natural pollination percentage to enable us to determine how many pollinator nests should be introduced into crop areas. The classification was based on passion fruit production data in different locations in Brazil (Sazima and Sazima, 1989; Kavati 1998; Camillo 2003; Oliveira-Filho and Freitas 2003; Bos et al. 2007) and in the Triângulo Mineiro region (Yamamoto et al. 2012). According to these study results, the average natural pollination percentage of passion fruit is $13.7 \pm 8.9 \%$ $($ Brazil $=15.7 \pm 10.3 \%$; Triângulo Mineiro = $11.1 \pm 6.4 \%$ ). Therefore, areas with natural pollination percentages over $13 \%$ were classified as areas with a low pollination deficit (LPD) and areas below $13 \%$ were classified as areas with a high pollination deficit (HPD).

We introduced four nests/ha, in three of the six selected study areas classified as LPD. In the remaining three, classified as HPD areas, we introduced eight nests/ha (Table I). We transferred the nests of $X$. frontalis and $X$. grisescen $\mathrm{s}$ from the breeding areas located in Uberlândia and Araguari, MG, with an average distance of $50 \mathrm{~km}$ from the passion fruit crops. Each nest contained only one female and presented no brood cells. We estimated that nests with no brood cells would exhibit a percentage of female permanence of approximately $50 \%$ (Junqueira et al. 2012) and with the number of nests introduced, we expected to get at least a fraction of pollination increase.

\subsection{Pollinator and thieves' densities}

We evaluated the density of pollinators and thieves in the passion fruit crop areas using the visitation rate, which was measured by the number of visits per flower per time unit through the

Table I. Location (coordinates), size (ha), percentage of natural pollination, and number of introduced nests in the passion fruit crop areas.

\begin{tabular}{lclll}
\hline & Location & Size (ha) & $\begin{array}{c}\text { \% Natural } \\
\text { pollination }\end{array}$ & $\begin{array}{c}\text { No. of introduced } \\
\text { nests }\end{array}$ \\
\hline Area 1 & $18^{\circ} 43^{\prime} 29^{\prime \prime} \mathrm{S} / 48^{\circ} 08^{\prime} 25^{\prime \prime} \mathrm{W}$ & 2 & 19.30 & 8 \\
Area 2 & $18^{\circ} 43^{\prime} 00^{\prime \prime} \mathrm{S} / 48^{\circ} 04^{\prime} 14^{\prime \prime} \mathrm{W}$ & 3 & 17.43 & 12 \\
Area 3 & $18^{\circ} 30^{\prime} 98^{\prime \prime} \mathrm{S} / 48^{\circ} 27^{\prime} 77^{\prime \prime} \mathrm{W}$ & 2 & 16.67 & 8 \\
Area 4 & $18^{\circ} 27^{\prime} 99^{\prime \prime} \mathrm{S} / 48^{\circ} 25^{\prime} 45^{\prime \prime} \mathrm{W}$ & 1 & 9.84 & 8 \\
Area 5 & $18^{\circ} 51^{\prime} 54^{\prime \prime} \mathrm{S} / 48^{\circ} 27^{\prime} 28^{\prime \prime} \mathrm{W}$ & 1 & 2.61 & 8 \\
Area 6 & $18^{\circ} 33^{\prime} 12^{\prime \prime} \mathrm{S} / 48^{\circ} 23^{\prime} 55^{\prime \prime} \mathrm{W}$ & 1 & 4.41 & 8 \\
\hline
\end{tabular}


transect census method (Dafni et al. 2005; Winfree et al. 2008). Visitation rates were evaluated for three consecutive days before and after the pollinator enhancement with the introduction of nests in each crop area.

We established two transects of $50 \mathrm{~m}$ in length and $2.5 \mathrm{~m}$ in width along the crop lines in each study area. Each transect was walked for $10 \mathrm{~min}$, at hourly intervals, between 1300 and 1600 hours with a sampling effort of $8 \mathrm{~h}$ per study area. We conducted all censuses on sunny and warm days, which displayed both the highest number of open flowers and the activity of bee species.

\subsection{Passion fruit production and quality}

The percentage of passion fruit formation was assessed by natural pollination experiments in each study area by marking 50 flowers per day during three consecutive days before and after the pollinator enhancement. These natural pollination experiments were made during the peak flowering and within a short time span (7 to 10 days) to avoid seasonal effects in fruit production. The flowers selected presented stylus with total curvature, which indicates the effective pollination period (Bruckner and Silva 2001) and were distributed in different plants along the crop lines.

The fruit quality was evaluated by measuring the following physical and chemical attributes: fruit weight $(\mathrm{g})$, flesh weight $(\mathrm{g})$, and number of seeds. The chemical attributes were evaluated through the relationship between soluble solids and the total titratable acidity. Soluble solids (SS) indicated the sugar content of fruit juice and were measured using juice from the pulp sample of each fruit by using a manual refractometer with results expressed in $\mathrm{Brix}^{\circ}$. Total titratable acidity (TTA) indicated the acid concentration in fruit juice and was determined by titrating diluted passion fruit flesh with a sodium hydroxide solution $\left(0.1 \mathrm{~mol} \mathrm{~L}^{-1}\right)$ in a Mettler Toledo® automatic titrator. We used $1 \mathrm{~g}$ of flesh pulp dissolved in $50 \mathrm{~mL}$ of distilled water and performed the titration in triplicate. Total acidity was expressed as percent of citric acid.

\subsection{Data analysis}

We conducted the data analysis using the statistical package Systat 10.2 (C) (2002), according to Zar (2000) and considered each observation day in the study areas as a sample unit. We used the Kolmogorov-Smirnov test (Lilliefors) $(P>0.05)$ to verify the normality of the data. For data that could not be normalized, we used nonparametric tests. Average values presented are followed by the standard deviation values. We used paired $t$ test to evaluate the effect of pollinator enhancement on pollinator and thieves' densities and to evaluate fruit production and quality before and after pollinator enhancement. We used the Spearman correlation to test the association of the percentage of natural fruit set with the density of pollinators and thieves. We used the paired $t$ test and Wilcoxon test to compare fruit quality parameters.

\section{RESULTS}

\subsection{Effect of pollinator enhancement on the pollinator and thieves' densities}

Considering the six study areas, we observed that pollinator enhancement promoted a significant increase in pollinator density of both LPD and HPD areas (LPD areas: $t=3.12 ; d f=16 ; P=$ 0.007; HPD areas: $t=-8.09$; $d f=16 ; P=0.005$ ) whereas the thieves' density presented a significant decrease (LPD areas: $t=3.69 ; d f=16 ; P=$ 0.002; HPD areas: $t=3.67 ; d f=16 ; P=0.002$ ) (Figure 1).

\subsection{Effect of pollinator enhancement on fruit production and quality}

Due to a plant bacterial disease in one of the study areas during data collection, we evaluated crop production and quality only in five study areas. Considering the classification of the study areas according to pollination deficits, the difference on percentage of natural fruit set after and before pollinator enhancement of LPD areas ranged from 11.83 to $33.33 \%$ and in HPD areas ranged from 21.74 to $42.68 \%$ (Figure 2). The average fruit production increment in the LPD areas was $108.93 \%$ while in 

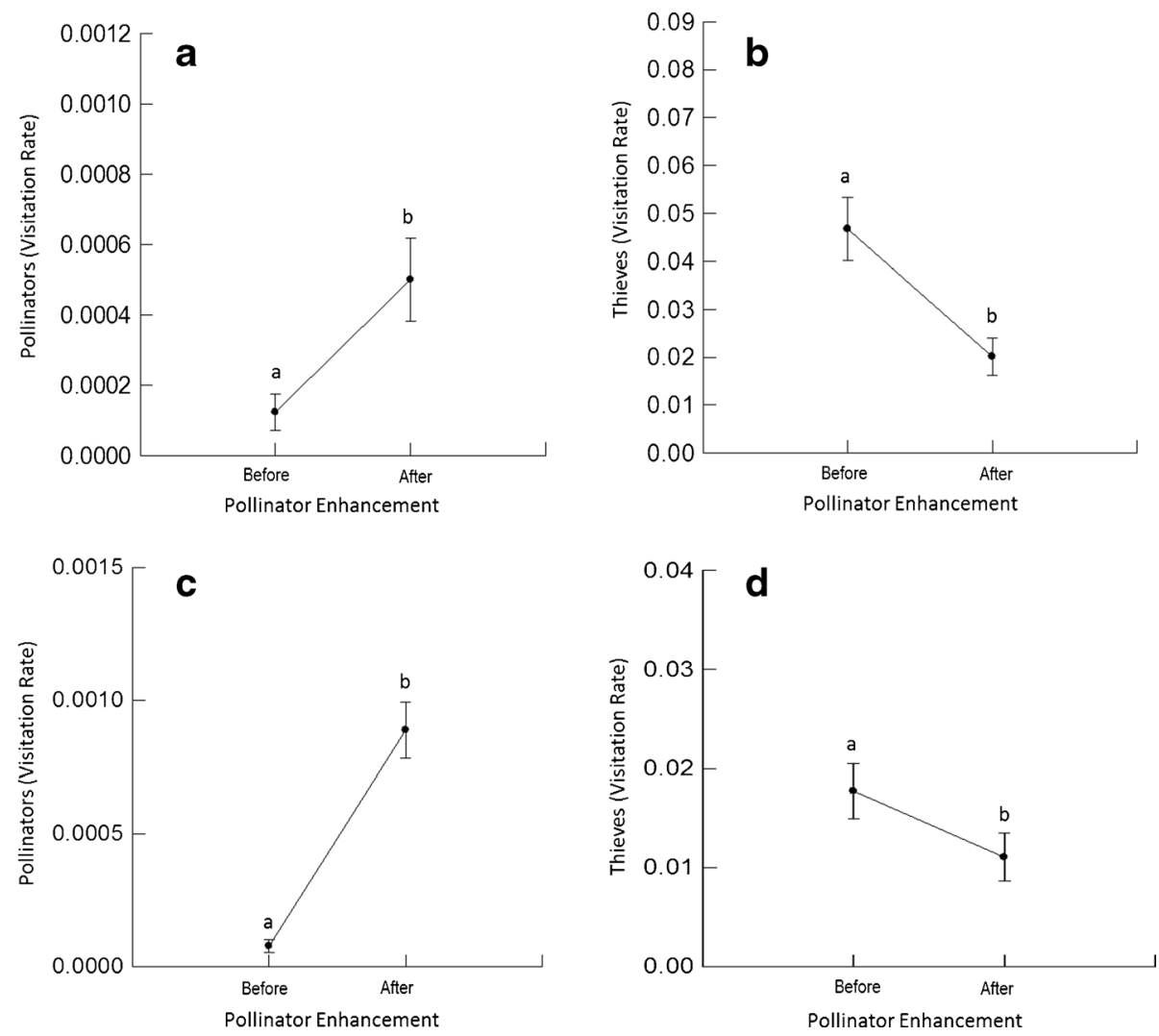

Figure 1. Average density $( \pm \mathrm{SE})$ of pollinators $(X$. frontalis and $X$. grisescens $)$ and thieves $(A$. mellifera and stingless bee species) calculated by visitation rate before and after pollinator enhancement in all study areas (a, b low pollination deficit areas; $\mathbf{c}, \mathbf{d}$ high pollination deficit areas). Superscript letters indicate equality or difference between sample means.

HPD areas was $961.13 \%(t=2.979 ; d f=13 ; P=$ 0.011) (Table II).

We also observed a positive correlation between the percentage of natural fruit set and pollinator density $\left(r_{s}=0.74 ; d f=30 ; P=0.001\right)$.
Diversely, the percentage of natural fruit set and the density of thieves bees presented a negative correlation $\left(r_{s}=-0.36 ; d f=30 ; P=0.002\right)$, which confirm the effect of pollinator enhancement on fruit set percentage.

Table II. Study areas classification (low pollination deficit (LPD), high pollination deficit (HPD)), percentage of natural fruit set before (BPE) and after pollinator enhancement (APE), and average fruit set increment.

\begin{tabular}{lllll}
\hline Study areas & Classification & Fruit set BPE (\%) & Fruit set APE (\%) & Fruit set increment (\%) \\
\hline 1 & LPD & $19.3 \pm 2.5$ & $45.3 \pm 6.8$ & 133.05 \\
3 & LPD & $16.7 \pm 2.1$ & $30.7 \pm 3.5$ & 84.82 \\
4 & HPD & $9.8 \pm 3.5$ & $48.1 \pm 3.2$ & 411.73 \\
5 & HPD & $2.6 \pm 0.8$ & $35.4 \pm 6.7$ & 1779.52 \\
6 & HPD & $4.4 \pm 1.3$ & $29.5 \pm 4.5$ & 692.13 \\
\hline
\end{tabular}



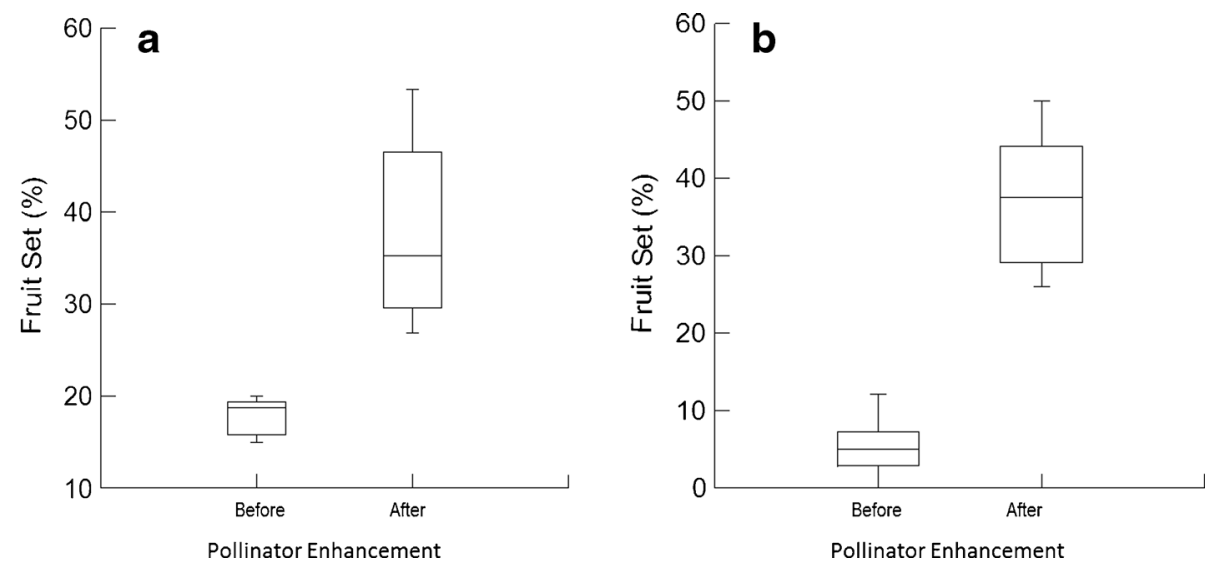

Figure 2. Increment of fruit set percentage assessed by natural pollination (percentage of fruit set) before and after pollinator enhancement in five study areas of passion fruit crop located in Uberlândia and Araguari, MG (a low pollination deficit areas; $\mathbf{b}$ high pollination deficit areas).

Pollinator enhancement was an effective method to improve physical and chemical characteristics of fruits in both LPD and HPD areas. Comparing fruits from natural pollination treatment before and after pollinator enhancement, in LPD areas, there was an increase of $46 \%$ in weight (fruit weight: $z=-8.27 ; P=0.03$ /flesh weight: $z=1.93 ; P=0.0142), 44 \%$ in seed number $(z=1.93 ; P=0.04)$ and $31 \%$ in sweetness $(t=-2.93 ; d f=18 ; P=0.009)$. To the HPD areas, we observed an increase of $45 \%$ in weight (fruit weight: $t=-4.02 ; d f=28 ; P=$ 0.001/flesh weight: $t=-3.64 ; d f=28 ; P=$ $0.001), 49 \%$ in seed number $(t=-4.24 ; d f=$ 28; $P=0.001)$ and $32 \%$ in sweetness $(z=$ 3.96; $P=0.001$ ) (Table III).

\section{DISCUSSION}

Our results demonstrated that pollinator enhancement was an efficient management technique to minimize pollination deficit in passion fruit crops since it promoted an increase in pollinator density, a decrease in thieves' density, and a significant rise in the number and quality of fruits.

The passion fruit is an interesting model to test solitary bee management procedures, as it is a crop that necessarily depends on pollination for adequate fruit formation (Corbet and Willmer 1980) and presents solitary bees with management potential as effective pollinators (Junqueira et al. 2013).

Table III. Physical and chemical characteristics of fruits from natural pollination treatment before pollinator enhancement (NP-BPE) and after pollinator enhancement (NP-APE) in areas with low pollination deficit (LPD) and with high pollination deficit (HPD).

Physical and chemical characteristics

\begin{tabular}{llll}
\hline Fruit weight $(\mathrm{g})$ & Flesh weight $(\mathrm{g})$ & \multicolumn{1}{c}{ Seed number } & $\begin{array}{c}\text { Soluble solids/ } \\
\text { titratable acidity }\end{array}$ \\
\hline $135.08 \pm 55.19 \mathrm{a}$ & $59.34 \pm 29.25 \mathrm{a}$ & $236.42 \pm 144.52 \mathrm{a}$ & $2.97 \pm 0.83 \mathrm{a}$ \\
$189.03 \pm 65.48 \mathrm{~b}$ & $89.89 \pm 29.32 \mathrm{~b}$ & $339.20 \pm 91.19 \mathrm{~b}$ & $3.88 \pm 0.97 \mathrm{~b}$ \\
$127.48 \pm 47.00 \mathrm{a}$ & $56.17 \pm 25.13 \mathrm{a}$ & $200.86 \pm 85.56 \mathrm{a}$ & $2.32 \pm 0.66 \mathrm{a}$ \\
$182.28 \pm 44.99 \mathrm{~b}$ & $82.21 \pm 29.87 \mathrm{~b}$ & $298.48 \pm 104.13 \mathrm{~b}$ & $3.06 \pm 0.77 \mathrm{~b}$ \\
\hline
\end{tabular}


Pollinator enhancement reduced the pollination deficit in passion fruit crops in all study areas. First, we verified that the increase in pollinator density was followed by a reduction in the visitation rate of thieves, corroborating previous studies (Junqueira et al. 2013). Passion fruit thieves include A. mellifera and stingless bee species, which may contribute to the reduction of the amount of nectar and/or pollen available and the visitation rate of pollinators, due to its recruitment behavior performed to food resource collection (Sazima and Sazima 1989; Maloof and Inouye 2000). The increase in the visitation rate of large pollinators with a high energy demand implies competition for nectar since there is a decrease in both quantity and quality of this resource, which negatively affect the density of thieves on passion fruit crop areas (Keasar 2000).

Pollinator enhancement in crop areas promoted an increment of both production and quality of passion fruits. A higher visitation rate of pollinators probably led to a higher pollen deposition, translated into higher crop production with improved quality. This effect confirms that there was a limitation of agricultural output in the studied crops due to a crop pollination deficit (Vaissière et al. 2011).

Pollination services present an overall impact on multiple aspects of production and quality of several crops, including the passion fruit. For strawberry (Fragaria $x$ ananassa Duch), there is a positive effect of bee pollination on fruit weight and shelf life (Klatt et al. 2014). Other studies have also demonstrated that chemical parameters, like the oil content in oilseed rape (Brassica napus) and sugar concentration in oranges (Citrus reticulata Blanco) were enhanced through pollination (Wallace and Lee 1999; Bommarco et al. 2013). As regards the passion fruit chemical attributes, our results support the finding of Silveira et al. (2012) substantiating that the pollination service can affect the SS/TTA relationship, which is generally used as a measurement for evaluating fruit flavor (Nascimento et al. 1999).

As a general result, the increase in pollinator density promoted the production of bigger and sweeter fruits, leading to a direct impact on the valuation of pollination services (Hanley et al. 2015). The pollinator enhancement resulted in an average increment in production of $27.4 \%$. Considering the average yield (16 t/ha) and the value of passion fruit per kilogram (US\$1.14) in the state of Minas Gerais, Brazil (Agrianual Anuário Estatístico da Agricultura Brasileira 2014), the economic value promoted by the enhanced pollinator services in these study areas was estimated at US\$5000 per hectare.

To refine pollinator management, we also defined how many bees are required to minimize the pollination deficit. To calculate the number of nests to be introduced in passion fruit crops, we considered the size of the area and natural pollination indices. Natural pollinator density is directly related to the yield and production quality of crops that rely on or benefit from pollination (Klein et al. 2007; Vaissière et al. 2011). For fruit pollination, using solitary bee species like Osmia cornifrons and $O$. cornuta, the density of pollinators is based on the crop size and is determined by the average number of bee visits and the number of flowers per tree (Vicens and Bosch 2000). To achieve positive yield effects on apple crops, 530 nesting females of $O$. cornuta per hectare are recommended and for almond pollination, 750 nesting females per hectare (Bosch and Kemp 2002). However, due to the size of carpenter bees and the long flight distance, the number of nests needed for pollination is lower compared with Osmia spp., for example (Freitas and Oliveira-Filho 2001; Gathamann and Tscharntke 2002).

We found similar results regarding production increment with previous studies involving carpenter bees management in passion fruit. One of the first studies in Brazil was conducted in a crop area with $3 \%$ of natural fruit set. The introduction of 25 nests per hectare promoted a variation of natural fruit set percentage of $22 \%$ with an increase of $700 \%$ in production (Camillo 2003). In another study in a crop area with $13 \%$ of natural fruit set, the introduction of seven nests placed in five rational nesting boxes per hectare promoted a variation of natural fruit set percentage of $12 \%$ with an increase of $92 \%$ in production (Freitas and Oliveira-Filho 2003).

The data obtained in our study highlight the importance of considering both the crop size and 
natural fruit set rates for calculating the amount of nests for a successful management of these pollinators. Those data are also essential to consolidate management techniques of carpenter bees in passion fruit crops. It is possible to rear and increase populations of these bees in crop areas using lowcost trap-nests as shown previously by other authors (Camillo 2003, Freitas and Oliveira-Filho 2003) and to increase pollinator density to produce bigger and sweeter passion fruits. Our study also showed the effect of bee pollination on fruit quality to further understand the real contribution of this ecosystem service.

\section{ACKNOWLEDGMENTS}

This study was supported by grants from the Fundação de Amparo à Pesquisa do Estado de Minas Gerais (FAPEMIG) and the Conselho Nacional de Desenvolvimento Científico e Tecnológico (CNPq). We are grateful to the passion fruit producers from Uberlândia and Araguari-MG for allowing our field work, to Pedro Gregol, agronomist at Empresa Brasileira de Bebidas e Alimentos (Ebba), for supporting the selection of the study areas and two anonymous reviewers for insightful comments that improved the manuscript. S.C. Augusto received research fellowships from $\mathrm{CNPq}$ and C. N. Junqueira received a fellowship from FAPEMIG.

Des fruits de la passion plus gros et plus sucrés: effet de l'accroissement des pollinisateurs sur la production et la qualité des fruits

Pollinisation des cultures / qualité du fruit / abeilles charpentières / aménagement de sites de nidification

Grössere und süssere Maracujafrüchte: Der Effekt einer verstärkten Bestäuberpräsenz auf die Fruchtproduktion und Qualität

Bestäubung / Fruchtqualität / Maracuja / Holzbiene / Nestmanagement

\section{REFERENCES}

Agrianual Anuário Estatístico da Agricultura Brasileira (2014) FNP Consultoria e Comércio, São Paulo, Brasil

Bell, M.C., Spooner-Hart, R.N., Haigh, A.M. (2006) Pollination of greenhouse tomatoes by the Australian bluebanded bee Amegilla (Zonamegilla) holmesi (Hymenoptera: Apidae). J. Econ. Entomol. 99, 437-442

Bispo dos Santos, S.A., Roselino, A.C., Hrncir, M., Bego, L.R. (2009) Pollination of tomatoes by the stingless bee Melipona quadrifasciata and the honey bee Apis mellifera (Hymenoptera, Apidae). Genet. Mol. Res. 8, 751-757Bommarco, R., Kleijn, D., Potts, S.G. (2013) Ecological intensification: Harnessing ecosystem services for food security. Trends Ecol. Evol. 28, 230-238

Bos, M.M., Veddeler, D., Bogdanski, A.K., Klein, A.M., Tscharntke, T., Steffan-Dewenter, I., Tylianakis, J.M. (2007) Caveats to quantifying ecosystem services: Fruit abortion blurs benefits from crop pollination. Ecol. Appl. 17, 1841-1849

Bosch, J., Kemp, W.P. (2001) How to manage the blue orchard bee, Osmia lignaria, as an orchard pollinator. Sustainable Agriculture Network, Washington

Bosch, J., Kemp, W.P. (2002) Developing and establishing bee species as crop pollinators : the example of Osmia spp. (Hymenoptera: Megachilidae) and fruit trees. Bull. Entomol. Res. 92, 3-16

Bruckner, C.H., Silva, M.M. (2001) Florescimento e frutificação. In: Bruckner, C.H., Pianço, M.C. (eds.) Maracujá tecnologia de produção, pós-colheita, agroindústria, mercado. Editora Cinco Continentes. Porto Alegre, Brazil, pp. 52-83

Camillo, E. (2003) Polinização de maracujá. Holos Editora, Ribeirão Preto

Corbet, S.A., Willmer, P.G. (1980) Pollination of the yellow passion fruit: nectar, pollen and carpenter bees. J. Agr. Sci. 95, 655-666

Dafni, A., Pacini, E., Nepi, M. (2005) Pollen and stigma biology. In: Dafni, A., Kevan, P.G., Husband, B.C. (eds.) Practical Pollination Biology, pp. 83-146. Enviroquest Ltd., Cambridge, Ontario

Dupont, Y.L., Damgaard, C., Simonsen, V. (2011) Quantitative historical change in bumblebee (Bombus spp.) assemblages of red clover fields. PLoS One 6, e25172

Ellis, A.M., Myers, S.S., Ricketts, T.H. (2015) Do Pollinators Contribute to Nutritional Health? PLoS One 10, e114805

Freitas, B.M., Oliveira-Filho, J.H. (2001) Criação racional de mamangavas para polinização em áreas agrícolas. Banco do Nordeste, Fortaleza

Freitas, B.M., Oliveira-Filho, J.H. (2003) Ninhos racionais para mamangava (Xylocopa frontalis) na polinização do maracujá-amarelo (Passiflora edulis ). Cienc. Rural. 33, 1135-1139

Gallai, N., Salles, J.M., Settele, J., Vaissière, B.E. (2009) Economic valuation of the vulnerability of world agriculture confronted with pollinator decline. Ecol. Econ. $\mathbf{6 8}, 810-821$

Garibaldi, L.A., Steffan-Dewenter, I., Winfree, R., Aizen, M.A., Bommarco, R., Cunningham, S.A., et al. (2013) Wild Pollinators Enhance Fruit Set of Crops Regardless of Honey Bee Abundance. Science 339, 1608-1611 
Gathamann, A., Tscharntke, T. (2002) Foraging ranges of solitary bees. J. Anim. Ecol 71, 757-764

Greenleaf, S.S., Kremen, C. (2006) Wild bees enhance honey bees' pollination of hybrid sunflower. Proc. Natl. Acad. Sci. U.S.A. 103 , 13890-13895

Hanley, N., Breeze, T.D., Ellis, C., Goulson, D. (2015) Measuring the economic value of pollination services: Principles, evidence and knowledge gaps. Ecosyst. Serv. 14, 1-9

Hogendoorn, K., Steen, Z., Schwarz, M.P. (2000) Native Australian carpenter bees as a potential alternative to introducing bumble bees for tomato pollination in greenhouses. J. Apic. Res. 39, 67-74

Javorek, A.S.K., Mackenzie, K.E., Kloet, Vander, S.P. (2002) Comparative Pollination Effectiveness Among Bees (Hymenoptera: Apoidea) on Lowbush Blueberry (Ericaceae: Vaccinium angustifolium). Ann. Entomol. Soc. Am 95, 345-351

Junqueira, C.N., Hogendoorn, K., Augusto, S.C. (2012) The use of trap-nests to manage carpenter bees (Hymenoptera: Apidae: Xylocopini), pollinators of passion fruit (Passifloraceae: Passiflora edulis $\mathrm{f}$. flavicarpa). Ann. Entomol. Soc. Am. 105, 884-889

Junqueira, C.N., Yamamoto, M., Oliveira, P.E., Hogendoorn, K., Augusto, S.C. (2013) Nest management increases pollinator density in passion fruit orchards. Apidologie 44, 729-737

Kavati, R. (1998) Florescimento e frutificação do maracujazeiro amarelo (Passiflora edulis f. flavicarpa). In: Ruggiero, C. (ed.) Maracujá do plantio à colheita, pp. 107-129. Funep, Jaboticabal

Keasar, T. (2000) The spatial distribution of nonrewarding artificial flowers affects pollinator attraction. Anim. Behav. 60, 639-646

Klatt, B.K., Holzschuh, A., Westphal, C., Clough, Y., Smit, I., Pawelzik, E., Tscharntke, T. (2014) Bee pollination improves crop quality, shelf life and commercial value. Proc. Biol. Sci. 281 , 20132440

Klein, A., Vaissière, B.E., Cane, J.H., SteffanDewenter, I., Cunningham, S.A., Kremen, C., Tscharntke, T. (2007) Importance of pollinators in changing landscapes for world crops. Proc. Biol. Sci. 274, 303-313

Magalhães, C.B., Freitas, B.M. (2012) Introducing nests of the oil-collecting bee Centris analis (Hymenoptera: Apidae: Centridini) for pollination of acerola (Malpighia emarginata) increases yield. Apidologie 44, 234-239

Maloof, J.E., Inouye, D.W. (2000) Are nectar robbers cheaters or mutualists? Ecology 81, 2651-2661

Michener, C.D. (2007) The bees of the world. The Johns Hopkins University Press, Baltimore

Nascimento, T.B., Ramos, J.D., Menezes, J.B. (1999) Características físicas do maracujá-amarelo produzido em diferentes épocas. Pesqui. Agropecu. Bras. 34, 2353-2358

Oliveira-Filho, J.H., Freitas, B.M. (2003) Colonização e biologia reprodutiva de (Xylocopa frontalis) $\mathrm{em}$ um modelo de ninho racional. Cienc. Rural. 33, 693-697

Pereira, M., Garófalo, C.A. (2010) Biologia da nidificação de Xylocopa frontalis e Xylocopa grisescens (Hymenoptera, Apidae, Xylocopini) em ninhosarmadilha. Oecol. Aust. 14, 193-209

Potts, S.G., Biesmeijer, J.C., Kremen, C., Neumann, P., Schweiger, O., Kunin, W.E. (2010) Global pollinator declines: trends, impacts and drivers. Trends Ecol. Evol. 25, 345-353

Pretty, J. (2008) Agricultural sustainability: concepts, principles and evidence. Philos. Trans. R. Soc. B Biol. Sci. $363,447-465$

Ricketts, T.H. (2004) Tropical Forest Fragments Enhance Pollinator Activity in Nearby Coffee Crops. Conserv. Biol. 18, 1262-1271

Rosa, R., Lima, S.C.C., Assunção, W.L. (1991) Abordagem preliminar das condições climáticas de Uberlândia (MG). S \& N 3, 91-108

Sazima, I., Sazima, M. (1989) Mamangavas e irapuás (Hymenoptera, Apoidea): visitas, interações e consequências para polinização do maracujá (Passifloraceae). Rev. Bras. Entomol 33, 109118

Silveira, M.V., Abot, A.R., Nascimento, J.N., Rodrigues, E.T., Rodrigues, S.R., Puker, A. (2012) Is manual pollination of yellow passion fruit completely dispensable? Sci. Hortic. 146, 99-103

Steward, P.R., Shackelford, G., Carvalheiro, L.G., Benton, T.G., Garibaldi, L.A., Sait, S.M. (2014) Pollination and biological control research: are we neglecting two billion smallholders. Agric. Food Secur. 3, 5

Thomson, J.D., Goodell, K. (2001) Pollen removal and deposition by honeybee and bumblebee visitors to apple and almond flowers. J. Appl. Ecol. 38, 10321044

Vaissière, B.E., Freitas, B.M., Gemmill-Herren, B. (2011) Protocol to detect and assess pollination deficits in crops: a handbook for its use. (FAO) Food and Agriculture Organization, Roma

Vicens, N., Bosch, J. (2000) Weather-Dependent Pollinator Activity in an Apple Orchard, with Special Reference to Osmia cornuta and Apis mellifera (Hymenoptera: Megachilidae and Apidae). Environ. Entomol. 29, 413-420

Wallace, H.M., Lee, L.S. (1999) Pollen source, fruit set and xenia in mandarins. J. Hortic. Sci. Biotech 74, 82-86

Westerkamp, C. (1991) Honeybees are poor pollinators why? Plant Syst. Evol. 177, 71-7

Wilcock, C., Neiland, R. (2002) Pollination failure in plants: Why it happens and when it matters. Trends Plant Sci. 7, 270-277

Winfree, R., Williams, N.M., Gaines, H., Ascher, J.S., Kremen, C. (2008) Wild bee pollinators provide the majority of crop visitation across land-use gradients in New Jersey and Pennsylvania, USA. J. Appl. Ecol. 45, 793-802 
Yamamoto, M., Da Silva, C.I., Augusto, S.C., Barbosa, A.A.A., Oliveira, P.E. (2012) The role of bee diversity in pollination and fruit set of yellow passion fruit (Passiflora edulis forma flavicarpa,
Passifloraceae) crop in Central Brazil. Apidologie. 43, 515-526

Zar, J.H. (2000) Biostatistical analysis, 5th edn. Prentice Hall, Upper Saddle River 